\title{
Differentiation-Inducing Activity of the Phyto-polyphenols Epigallocatechin- 3-gallate and Kaempferol on NB4 Cells
}

\author{
Mohammad Hassan Jokar + (iD), Sima Sedighi + (iD), Maliheh Moradzadeh* id \\ 1. Golestan Rheumatology Research Center, Sayad Shirazi Hospital, Golestan University of Medical Sciences, Gorgan, \\ Iran
}

\begin{tabular}{|c|c|}
\hline Article Info & ABSTRACT \\
\hline doi $10.30699 /$ jambs.29.137.125 & \multirow{3}{*}{$\begin{array}{l}\text { Background \& Objective: The rate of survival in acute promyelocytic leukemia } \\
\text { (APL) can dramatically improve, if the patients receive all-trans-retinoic acid } \\
\text { (ATRA) treatment. However, this drug's toxicity is a major problem in APL } \\
\text { treatment. Previous researches have demonstrated that phyto-polyphenols such as } \\
\text { epigallocatechin gallate (EGCG) and kaempferol cause apoptosis in hematopoietic } \\
\text { neoplasms, but do not negatively impact healthy cells. The present study compared } \\
\text { the differentiation effects of kaempferol and EGCG, as well as ATRA in NB4 } \\
\text { leukemia cells during five days. }\end{array}$} \\
\hline $\begin{array}{l}\text { Received: 2020/10/19; } \\
\text { Accepted: 2021/02/25; } \\
\text { Published Online: } 01 \text { Aug 2021; }\end{array}$ & \\
\hline $\begin{array}{l}\text { Use your device to scan and read the } \\
\text { article online }\end{array}$ & \\
\hline \multirow{2}{*}{ 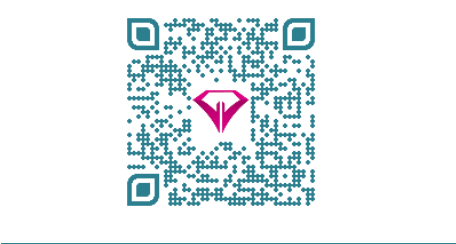 } & $\begin{array}{l}\text { Materials \& Methods: Herein, kaempferol and EGCG's differentiation-inducing } \\
\text { activity was examined by NBT assay and Real-time PCR in leukemia NB4 cells. }\end{array}$ \\
\hline & $\begin{array}{l}\text { Results: EGCG }(25 \mu \mathrm{M}) \text { and kaempferol }(50 \mu \mathrm{M}) \text { induced the NB4 cells' } \\
\text { differentiation, towards a granulocytic pattern similar to ATRA }(1 \mu \mathrm{M}) \text {. EGCG further } \\
\text { suppressed PML/RAR } \alpha \text { clinical marker's expression compared to kaempferol, it also } \\
\text { decreased HDAC1 expression in leukemia NB4 cells. }\end{array}$ \\
\hline \multirow{3}{*}{$\begin{array}{l}\text { Corresponding Information: } \\
\text { Maliheh Moradzadeh, } \\
\text { Golestan Rheumatology Research Cen- } \\
\text { ter, Sayad Shirazi Hospital, Golestan } \\
\text { University of Medical Sciences, Gor- } \\
\text { gan, Iran } \\
\text { E-Mail: : Moradzadeh63@yahoo.com }\end{array}$} & $\begin{array}{l}\text { Conclusion: Based on this study, compared to kaempferol, EGCG at low } \\
\text { concentrations is preferred for long-term ATRA therapy in APL patients. }\end{array}$ \\
\hline & $\begin{array}{l}\text { Keywords: Acute promyelocytic leukemia; Epigallocatechin gallate; Kaempferol; } \\
\text { Differentiation; HDAC1; PML/RAR } \alpha\end{array}$ \\
\hline & t: These authors contributed equally to this paper. \\
\hline (c) (i) (1) & $\begin{array}{l}\text { ss article distributed under the terms of the Creative Commons Attribution-nonco } \\
\text { oncommercial usages with proper citation. }\end{array}$ \\
\hline
\end{tabular}

\section{Introduction}

As a subtype of acute myeloid leukemia (AML), acute promyelocytic leukemia (APL) is characterized by chromosomal translocation $\mathrm{t}(15 ; 17)(\mathrm{q} 22 ; \mathrm{q} 21)$, causing a fusion between promyelocytic leukemia (PML) genes and the retinoic acid receptor- $\alpha(\mathrm{RAR} \alpha)$; the fusion also recruits histone deacetylases (HDACs), thereby repressing retinoic acid's differentiating role (1). Thus, HDAC inhibitors are regarded as important therapeutic agents for this type of leukemia $(2,3)$.

The use of all-trans retinoic acid (ATRA) for treating APL patients may markedly improve the survival rate. Still, in spite of the progress in the prognosis of most patients with APL, resistance to ATRA and disease relapse are still serious problems (4). Researchers hold that dietary phytochemical agents might impact chemotherapy and assist in the treatment of cancer. Various natural compounds (e.g. polyphenolic or flavonoids) can enhance chemotherapeutic agents' efficiency, ameliorate the adverse side-effects of chemotherapy and decrease chemotherapeutic drugs' resistance (5).
We previously reported that phyto-polyphenols epigallocatechin-3-gallate (EGCG) and kaempferol generally exert pleiotropic impacts on leukemic cells; they improve multiple signaling pathways and influence several dimensions of cellular fate, such as: cell differ-entiation, proliferation, and apoptosis. These natural com-pounds also induce death in tumor cells, while sparing normal cells (6-10).

EGCG is one of the main constituents of green tea. It demonstrates significant cancer chemo preventive and therapeutic potentials against different types of cancer (11). At present, 30 phase I and phase II clinical trials are in progress or in development in the USA, highlighting the potential value of this substance as a chemotherapeutic agent (12). The safety of EGCG has extensively been assessed (13), and green tea extract (Veregen, PharmaDerm, Florham Park, NJ, USA) has recently received the approval of the US Federal Drug Administration as the first botanical drug in the US $(14,15)$. EGCG inhibits AML cell lines and primary AML blast cells' prolifera- 
tion, but does not impact normal haematopoietic progenitor cells' colony-forming capacity (16).

Kaempferol is a yellow-colored flavonoid broadly distributed in botanical families such as: Albizia lebbeck, Adansonia digitata, Aloevera, strawberries, tomatoes and apple (17). Kaempferol's potential anticancer impacts on ovarian, colon, lung, prostate, esophageal, and pancreatic cancer cell lines have been documented in several studies (18-20). It has also been reported to reduce the resistance of cancer cells to anti-cancer drugs including vinblastine and paclitaxel (21). The mechanisms causing the anticancer effect of this substance are cell proliferation inhibition, antioxidant activity, apoptosis induction, and cell differentiation stimulation (22).

In previous studies, we have demonstrated the shortterm in vitro exposure of EGCG and kaempferol on APL cell lines $(6,7)$. In this study, the differentiation-inducing activity of kaempferol and EGCG was compared in the human promyelocytic leukemia NB4 cells for a five-day period. Another goal of the study was to determine whether there is an association between the anti-leukemic effects of kaempferol and EGCG and altered expression of PML-RAR $\alpha$ and HDAC1 in the long term.

\section{Materials and Methods}

\section{Chemicals and reagents}

High-glucose Roswell Park Memorial Institute (RPMI 1640) medium and fetal bovine serum (FBS) were procured from Gibco (USA). TRIzol was prepared from Invitrogen (USA). Moreover, the penicillin-streptomycin solution, all-trans retinoic acid (ATRA), nitro blue tetrazolium (NBT), phorbol myristate acetate (PMA), kaempferol $(>97 \%)$ and EGCG $(>95 \%)$ were purchased from Sigma-Aldrich (USA). The Giemsa-staining solution was obtained from Merck (Germany). Human promyelocytic leukemia NB4 cell line was purchased from the cell bank of Pasteur Institute (Iran). Moreover, real-time PCR Master Mix and cDNA synthesis Kit were procured from Roche Diagnostic (Switzerland) and Fermentas (Lithuania), in respective order.

The ethical approval code of the study is IR.JUMS.REC.1394.173.

\section{Differentiation assay}

Morphological observation was performed by Giemsa staining and NBT reduction assay to assess cell differentiation. To perform the NBT assay, treated cells with EGCG (6.25-50 $\mu \mathrm{M})$, kaempferol (12.5-100 $\mu \mathrm{M})$, or ATRA $(1 \mu \mathrm{M})$ were washed with PBS and suspended in the NBT solution $(2 \mathrm{mg} / \mathrm{ml})$, which contained $200 \mathrm{ng} / \mathrm{ml}$ of phorbol myristate acetate. Following $25 \mathrm{~min}$ of incubation at $37^{\circ} \mathrm{C}$ in the dark, the cytospin slides were stained with Giemsa. The differentiated cells were then identified based on their intracellular decreased dark blue formazan granules (300 cells measured for the presence of granules) (23).

\section{Real-time PCR quantification}

The cells treated with EGCG $(25 \mu \mathrm{M})$, kaempferol (50 $\mu \mathrm{M})$, or ATRA $(1 \mu \mathrm{M})$ underwent RNA extraction via TRIzol based on the manufacturer's guidelines. Spectrophotometry was performed to determine RNA concentration and purity. cDNA was synthesized from the total RNA (100 ng) of each sample by using a cDNA synthesis kit with a random hexamer primer.

Beacon software (ABI, USA) was used to design the primers and probes. Gene expression changes of differentiation (PML-RAR $\alpha$, HDAC1) were measured using TaqMan-based real-time PCR by the ABI Step One plus detection system (ABI, USA) (6).

\section{Western blot analysis}

Following five days of kaempferol $(50 \mu \mathrm{M})$, EGCG $(25 \mu \mathrm{M})$ and ATRA $(1 \mu \mathrm{M})$ treatment, lysis buffer was used to lyse the cells. The lysates were examined for the protein expression of acetyl-H3K4, which was detailed in ref. (24).

\section{Statistical analysis}

The data were expressed as mean \pm SEM; they were analyzed by one-way analysis of variance (ANOVA) with Tukey's multiple comparisons post-test. The p-value $<0.05$ was set as statistically significant. The statistical analysis was performed in Graph Pad PRISM software (Version 6, Graph Pad Software, CA).

\section{Results}

\section{EGCG and Kaempferol increased differentiation in NB4 cells}

Figure 1A displays the morphological analysis of leukemic cells by Giemsa staining. The untreated leukemic cells demonstrated promyelocytic characteristics including a large nucleus and granules in the cytoplasm. After EGCG $(<25 \mu \mathrm{M})$ and kaempferol $(<50$ $\mu \mathrm{M})$ treatment, the cells started to indicate morphological changes towards possessing hollow nuclei and greater zones of clear cytoplasm. After five days of treatment, a granulocytic maturation pattern was observed in the EGCG-, kaempferol-, and ATRA-treated cells; the nucleito-cytoplasm ratio was reduced, and the nuclei showed a range of remodeling from simple indentations to polylobular nuclei.

Compared to untreated control cells, in leukemic cells, EGCG- and kaempferol-treated cells demonstrated enhanced NBT reduction potential (the sign of granulocytic maturation), similarly to the positive control (Fig. 1B). NBT positive cells percentage in EGCG and kaempferol groups were $75 \pm 3.15$ and $40 \pm 4.15$, respectively, as compared to $85 \pm 5.57$ for ATRA-treated cells during five days exposure $(\mathrm{p}<0.001$, Fig. 1C). The impact of EGCG on NB4 cells' NBT reduction capacity was more pronounced than kaempferol. The $\mathrm{EC}_{50}$ values of EGCG and kaempferol equaled 15.91 \pm 0.06 and $102.20 \pm 0.07 \mu \mathrm{M}$ in NB4 cells at five days of incubation, respectively ( $\mathrm{p}<0.001$, Fig. $1 \mathrm{C})$. 
EGCG and Kaempferol reduced HDAC1 and PML-RAR $\alpha$ genes' expression in NB4 cells

Based on Figure 2A, five days of treatment with $50 \mu \mathrm{M}$ kaempferol and $25 \mu \mathrm{M}$ EGCG significantly reduced the expression of the PML-RAR $\alpha$ gene in NB4 cells $(0.84 \pm 0.04 ; \quad 0.33 \pm 0.07, \quad \mathrm{p}<0.001)$. Furthermore, in comparison to the untreated control cells, kaempferol and EGCG significantly reduced the HDAC1 gene expression in NB4 cells $(0.63 \pm 0.04 ; 0.51 \pm 0.03, \mathrm{p}<0.05)$.
To examine the effect of EGCG and kaempferol on HDAC1, its substrate level was assessed by Western blot analysis (Figure 2B). The histone H3K4ac (acetyl-H3K4) protein levels significantly raised in NB4 cells treated with $25 \mu \mathrm{M}$ of EGCG and $1 \mu \mathrm{M}$ of ATRA $(1.5 \pm 0.16$ and $1.7 \pm 0.21$, respectively; $p<0.001)$, thereby affirming the inhibitory effect of EGCG on HDAC1. Compared to EGCG, kaempferol did not significantly raise the acetyl$\mathrm{H} 3 \mathrm{~K} 4$ protein expression in the cells after five days (Figure 2C).

A

B
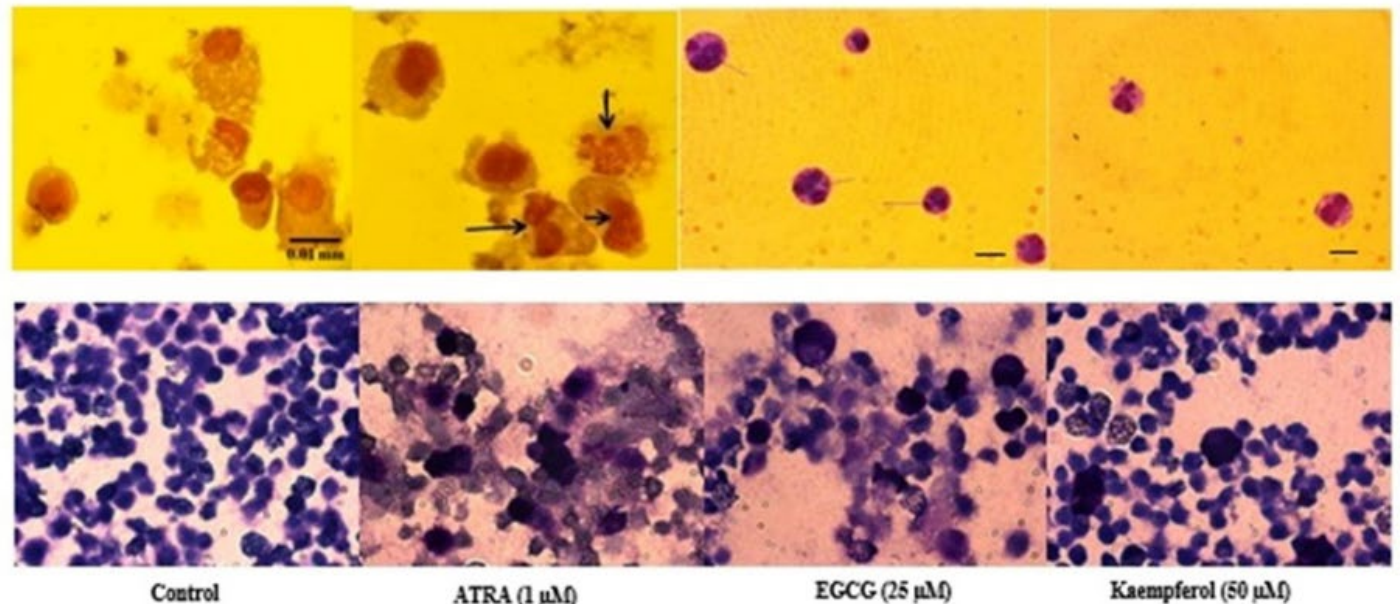

C

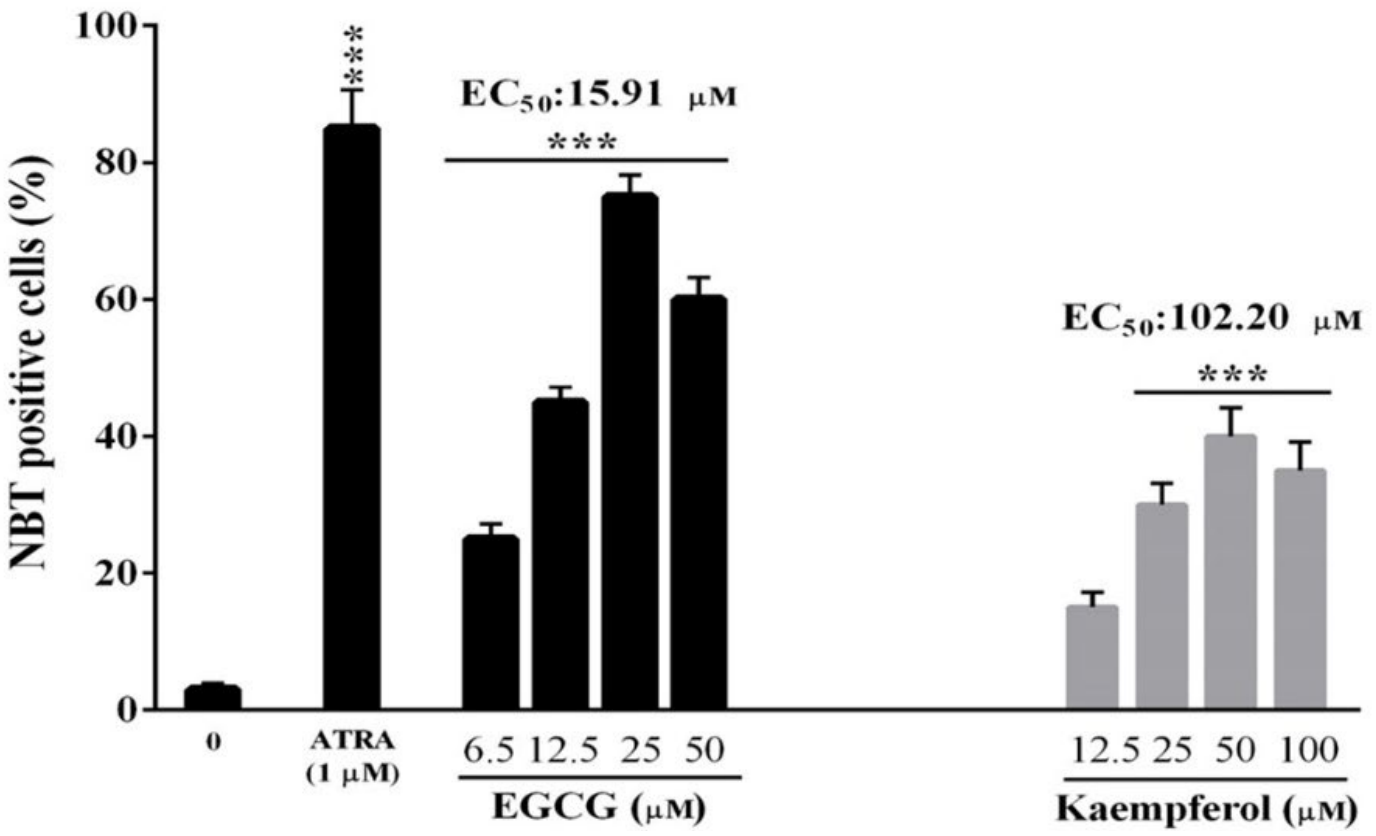

Figure 1. Effects of EGCG and kaempferol on the differentiation and granulocytic morphology of leukemia NB4 cells as determined by NBT assay and Giemsa staining, respectively. (A) The cells were incubated for five days with EGCG (6.25$50 \mu M)$, kaempferol (12.5-100 $\mu$ M), or all-trans retinoic acid (ATRA). Control APL cells showed a promyelocyte trait with granules in the cytoplasm. In the treated cells, the arrows show the polymorphonuclear morphology of granulocyte (the bar shows $0.01 \mathrm{~mm}$ ). (B) The photomicrographs of the NBT stained leukemic cells, which were treated for five days with EGCG, kaempferol, or ATRA. Black spots indicate dark blue formazan deposits in differentiated cells. (C) Differentiated cells in (B) section were analyzed quantifiably. A minimum of 300 cells were measured. Results were reported as means \pm SEM of three independent experiments. $* * * p<0.001$ vs. control cells. 
A

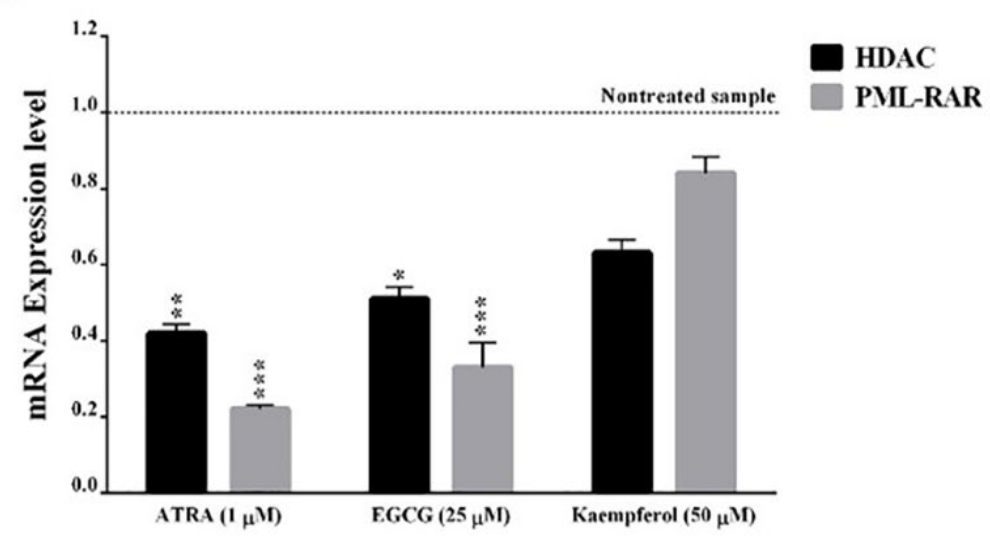

B

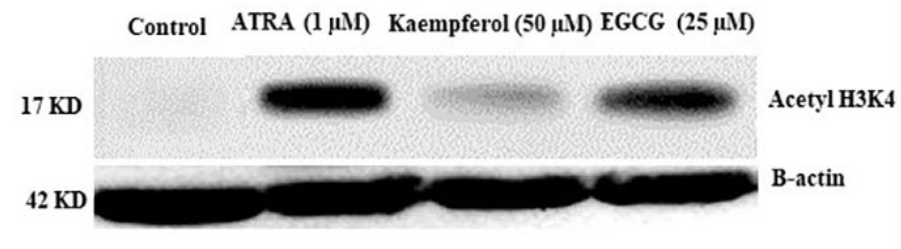

C

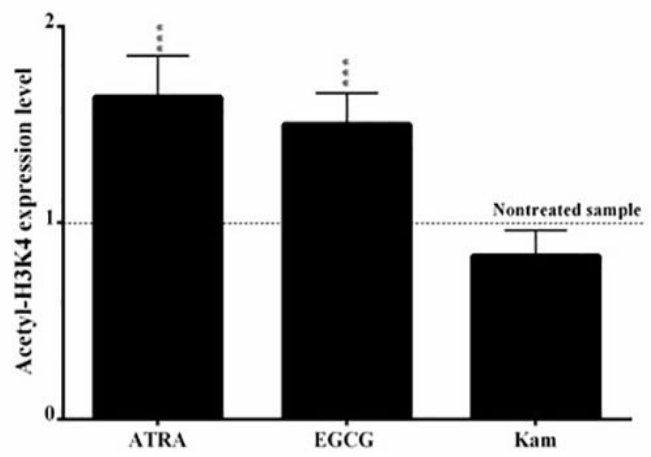

Figure 2. Effects of EGCG and kaempferol on HDAC1 and PML-RARa genes' expression in leukemia NB4 cells. (A) The cells were incubated for five days with EGCG, kaempferol, or all-trans retinoic acid (ATRA), and the expressions of HDAC1 and PML-RARa genes were measured by real-time PCR. (B) HDAC1 substrate (acetyl-H3K4) determined by Western blot. (C) the bands in (B) section were analyzed quantifiably. The results were reported as mean $\pm \mathrm{SEM}$ of three independent experiments. ${ }^{*} \mathrm{p}<0.05, * * p<0.01, * * * p<0.001$ vs. control cells.

\section{Discussion}

APL patients are successfully treated with ATRA, but resistance to this drug and its toxicity are the chief obstacles for APL treatment (25). Currently, some plant-derived compounds including taxol analogs and podophyllotoxin have been widely employed for chemotherapy $(26,27)$. In previous studies, we had reported that EGCG and kaempferol inhibited cell growth, promoted apoptosis, and induced differentiation in leukemia NB4 and HL60 cells during shortterm exposure. Even though the IC50 values obtained for EGCG and kaempferol's antiproliferative impact on leukemic cells were higher than the values for ATRA, but anti-proliferative effects were seen at concentrations with no evident toxic impact on normal polymorphonuclear cells; thus showing EGCG and kaempferol actions' specificity in leukemic cells $(6,7)$. In the present study, it was shown that EGCG promoted differentiation more than kaempferol in the NB4 cells through HDAC1 and PML-RAR $\alpha$ inhibition in a fiveday period.

A failure differentiate is the salient feature of promyelocytes in APL patients (28). The outcomes of Giemsa staining and NBT assay demonstrated that EGCG, like ATRA, causes morphological alterations in leukemic cells towards a granulocytic pattern, and promotes their NBT reduction potential, which indicates granulocytic maturation. EGCG's prodifferentiating action was observed at the $<25 \mu \mathrm{M}$ concentration; the effect was consistent with previously reported findings, which indicated that EGCG induced differentiation in different cancer cells (29-33).

On the other hand, Vézina et al. reported that EGCG might not pharmacologically impact the differentiated macrophage in neuroinflammation diseases (34). EGCG's inhibitory impact on PML-RAR $\alpha$ expression might express its prodifferentiating action on NB4 cells. It is recognized that fusions between PML and RAR recruit HDACs, in this way suppress genes associated with differentiation (35). Our data revealed that EGCG treatment decreased the HDAC1 expression in leukemic cells. In a previous study, we had concluded that EGCG promoted differentiation with EC50 $20.46 \pm 0.05$ and $35.58 \pm 0.07 \mu \mathrm{M}$ in leukemia NB4 and HL60 cells in three days of incubation, respectively $(\mathrm{p}<0.001)$.

We had also reported that EGCG decreased PMLRAR $\alpha$ gene expression in NB4 cells $(0.41 \pm 0.04$, $\mathrm{p}<0.001)$ and reduced HDAC1 gene expression $0.68 \pm$ 
0.03 and $0.75 \pm 0.05$ fold in three days in NB4 and HL60 cells, respectively $(p<0.001)(6)$. The findings of this study revealed that the EC50 value of EGCG equaled $15.91 \pm 0.06 \mu \mathrm{M}$ in NB4 cells in five days of incubation ( $\mathrm{p}<0.001$, Fig. 1C). Also, EGCG signifycantly decreased PML-RAR $\alpha$ and HDAC1 expression in NB4 cells in a five-day exposure $(0.33 \pm 0.07$ with $p$ $<0.001$ and $0.51 \pm 0.03$ with $\mathrm{p}<0.05$, respectively, in Fig. 2). Based on these data, EC50 of EGCG was significantly improved from three to five days $(\mathrm{p}<$ 0.001), without dramatically decreasing HDAC1 and PML-RAR $\alpha$ expressions in NB4 cells.

In our previous study, we had concluded that, contrary to ATRA, kaempferol did not induce differentiation in leukemic cells towards a granulocytic pattern over three days. Thus, kaempferol did not significantly inhibit PML-RAR $\alpha$ and HDAC1 expression level in NB4 cells (7). It did not significantly raise the HDAC1 substrate's protein expression in the leukemic cells after five days either.

According to the reported findings of present study, the EC50 of kaempferol was significantly improved from three to five days in NB4 cells $(217.6 \pm 0.06$ vise $102.20 \pm 0.07 \mu \mathrm{M}, \mathrm{p}<0.001)$. As compared to three days, kaempferol significantly decreased the expression of the HDAC1 gene during five days in leukemic cells $(0.95 \pm 0.03$ vise $0.63 \pm 0.04, p<0.05)$. Based on these results, the differentiation-inducing activity of kaempferol may occur via inhibition of HDAC1 in leukemia NB4 cells for five days. Previous studies have reported, that kaempferol inhibited growth in HL60 cells, that had not yet differentiated $(36,37)$. On the contrary, Kang et al. concluded that kaempferol did not impact F9 cell growth (38).

\section{Conclusion}

EGCG and kaempferol exert prodifferentiating influences on human leukemia NB4 cells through inhibiting HDAC1 and PML-RAR $\alpha$ expressions in long-term exposure. Accordingly, compared to kaempferol, EGCG at low concentrations can be efficient for long-term ATRA therapy in patients with APL.

\section{Acknowledgments}

None.

\section{Conflict of Interest}

None.

\section{References}

1. Adams J, Nassiri M. Acute promyelocytic leukemia: a review and discussion of variant translocations. Arch Pathol Lab Med. 2015;139(10):1308-13. [DOI:10.5858/arpa.2013-0345-RS]

2. Lo-Coco F, Hasan SK. Understanding the molecular pathogenesis of acute promyelocytic leukemia. Best Pract Res Clin Haematol. 2014;27(1):3-9. [DOI:10.1016/j.beha.2014.04.006]

3. Minucci S, Nervi C, Coco FL, Pelicci PG. Histone deacetylases: a common molecular target for differentiation treatment of acute myeloid leukemias? Oncogene. 2001;20(24):3110.

\section{[DOI:10.1038/sj.onc.1204336]}

4. Tomita A, Kiyoi H, Naoe T. Mechanisms of action and resistance to all-trans retinoic acid (ATRA) and arsenic trioxide (As2O3) in acute promyelocytic leukemia. Int J Hematol. 2013;97(6):717-25. [DOI:10.1007/s12185-013-1354-4]

5. Surh Y-J. Cancer chemoprevention with dietary phytochemicals. Nature Reviews Cancer. 2003;3(10):768-80. [DOI:10.1038/nrc1189]

6. Moradzadeh M, Roustazadeh A, Tabarraei A, Erfanian S, Sahebkar A. Epigallocatechin-3-gallate enhances differentiation of acute promyelocytic leukemia cells via inhibition of PML-RAR $\alpha$ and HDAC1. Phytother Res. 2018;32(3):471-9. [DOI:10.1002/ptr.5990]

7. Moradzadeh M, Tabarraei A, Sadeghnia HR, et al. Kaempferol increases apoptosis in human acute promyelocytic leukemia cells and inhibits multidrug resistance genes. J Cell Biochem. 2018;119(2):228897. [DOI:10.1002/jcb.26391]

8. Moradzadeh M, Hosseini A, Erfanian S, Rezaei H. Epigallocatechin-3-gallate promotes apoptosis in human breast cancer T47D cells through downregulation of PI3K/AKT and Telomerase. Pharmacol Reports. 2017;69(5):924-8. [DOI:10.1016/i.pharep.2017.04.008]

9. Kashafi E, Moradzadeh M, Mohamadkhani A, Erfanian S. Kaempferol increases apoptosis in human cervical cancer HeLa cells via PI3K/AKT and telomerase pathways. Biomed Pharmacother. 2017;89:573-7.

[DOI:10.1016/j.biopha.2017.02.061]

10. Moradzadeh M, Tayebi S, Poustchi $\mathrm{H}$, et al. The possible role of TLR2 in chronic hepatitis B patients with precore mutation. Adv Virol. 2013;2013. [DOI:10.1155/2013/780319]

11. Samodien S, Kock Md, Joubert E, Swanevelder S, Gelderblom WC. Differential cytotoxicity of rooibos and green tea extracts against primary rat hepatocytes and human liver and colon cancer cells-causal role of major flavonoids. Nutr Cancer. 2020:1-15. [DOI:10.1080/01635581.2020.1820054]

12. Kawasaki BT, Hurt EM, Mistree T, Farrar WL. Targeting cancer stem cells with phytochemicals. Molec Intervent. 2008;8(4):174. [DOI:10.1124/mi.8.4.9] 
13. Chow HS, Cai Y, Hakim IA, et al. Pharmacokinetics and safety of green tea polyphenols after multiple-dose administration of epigallocatechin gallate and polyphenon $\mathrm{E}$ in healthy individuals. Clin Cancer Res. 2003;9(9):3312-9.

14. Wu KM, Ghantous H, Birnkrant DB. Current regulatory toxicology perspectives on the development of herbal medicines to prescription drug products in the United States. Food Chem Toxicol. 2008;46(8):260610. [DOI:10.1016/j.fct.2008.05.029]

15. Liang K, Bae KH, Nambu A, et al. A two-pronged antileukemic agent based on a hyaluronic acid-green tea catechin conjugate for inducing targeted cell death and terminal differentiation. Biomater Sci. 2020;8(1):497505. [DOI:10.1039/C9BM01146C]

16. Otsuka T, Ogo T, Eto T, Asano Y, Suganuma M, Niho Y. Growth inhibition of leukemic cells by (-)epigallocatechin gallate, the main constituent of green tea. Life Sci. 1998;63(16):1397-403. [DOI:10.1016/S0024-3205(98)00406-8]

17. Li H, Yang L, Zhang Y, Gao Z. Kaempferol inhibits fibroblast collagen synthesis, proliferation and activation in hypertrophic scar via targeting TGF- $\beta$ receptor type I. Biomed Pharmacother. 2016;83:96774. [DOI:10.1016/j.biopha.2016.08.011]

18. Chen AY, Chen YC. A review of the dietary flavonoid, kaempferol on human health and cancer chemoprevention. Food Chem. 2013;138(4):2099-107. [DOI:10.1016/i.foodchem.2012.11.139]

19. Kim SH, Choi KC. Anti-cancer effect and underlying mechanism (s) of kaempferol, a phytoestrogen, on the regulation of apoptosis in diverse cancer cell models. Toxicol Res. 2013;29(4):229. [DOI:10.5487/TR.2013.29.4.229]

20. Abdullah A, Talwar P, d'Hellencourt CL, Ravanan P IRE $1 \alpha$ is critical for Kaempferol-induced neuroblastoma differentiation. FEBS J. 2019;286(7):1375-92. [DOI:10.1111/febs.14776]

21. Limtrakul P, Khantamat O, Pintha K. Inhibition of Pglycoprotein function and expression by kaempferol and quercetin. J Chemother. 2005;17(1):86-95 [DOI:10.1179/joc.2005.17.1.86]

22. Kanadaswami C, Lee L-T, Lee P-PH, et al. The antitumor activities of flavonoids. In Vivo. 2005;19(5):895-909.

23. Gupta K, Stefan T, Ignatz-Hoover J, et al. GSK-3 inhibition sensitizes acute myeloid leukemia cells to 1 , 25D-mediated differentiation. Cancer Res. 2016;76(9):2743-53. [DOI:10.1158/00085472.CAN-15-2290]

24. Moradzadeh M, Ghorbani A, Erfanian S, et al. Study of the mechanisms of crocetin-induced differentiation and apoptosis in human acute promyelocytic leukemia cells. J Cell Biochem. 2019;120(2):1943-57. [DOI:10.1002/jcb.27489]
25. Tomita A, Kiyoi H, Naoe T. Mechanisms of action and resistance to all-trans retinoic acid (ATRA) and arsenic trioxide (As2o3) in acute promyelocytic leukemia. Int J Hematol. 2013;97(6):717. [DOI:10.1007/s12185013-1354-4]

26. Karthick T, Tandon P. Computational approaches to find the active binding sites of biological targets against busulfan. J Mol Model. 2016;22(6):1-9. [DOI:10.1007/s00894-016-3015-Z]

27. Moradzadeh M, Kalani MR, Avan A. The antileukemic effects of saffron (Crocus sativus L.) and its related molecular targets: A mini review. J Cell Biochem. 2019;120(4): 4732-8. [DOI:10.1002/jcb.27525]

28. Petrie K, Zelent A, Waxman S. Differentiation therapy of acute myeloid leukemia: past, present and future. Curr Opin Hematol. 2009;16(2):84-91. [DOI:10.1097/MOH.0b013e3283257aee]

29. Lea MA, Xiao Q, Sadhukhan AK, Cottle S, Wang ZY, Yang CS. Inhibitory effects of tea extracts and (-) epigallocatechin gallate on DNA synthesis and proliferation of hepatoma and erythroleukemia cells. Cancer Lett. 1993;68(2):231-6. [DOI:10.1016/03043835(93)90151-X]

30. Annabi B, Currie JC, Moghrabi A, Béliveau R. Inhibition of HuR and MMP-9 expression in macrophage-differentiated HL-60 myeloid leukemia cells by green tea polyphenol EGCg. Leuk Res. 2007;31(9):1277-84 [DOI:10.1016/j.leukres.2006.10.001]

31. Huang AC, Cheng HY, Lin TS, et al. Epigallocatechin gallate (EGCG), influences a murine WEHI-3 leukemia model in vivo through enhancing phagocytosis of macrophages and populations of Tand B-cells. In Vivo. 2013;27(5):627-34.

32. Britschgi A, Simon HU, Tobler A, Fey MF, Tschan MP. Epigallocatechin-3-gallate induces cell death in acute myeloid leukaemia cells and supports all-trans retinoic acid-induced neutrophil differentiation via death-associated protein kinase 2. Br J Haematol. 2010;149(1):55-64.

[DOI:10.1111/j.13652141.2009.08040.x]

33. Chokor R, Lamy S, Annabi B. Transcriptional targeting of sphingosine-1-phosphate receptor S1P2 by epigallocatechin-3-gallate prevents sphingosine-1phosphate-mediated signaling in macrophagedifferentiated HL-60 promyelomonocytic leukemia cells. Onco Targets Ther. 2014;7:667. [DOI:10.2147/OTT.S62717]

34. Vézina A, Chokor R, Annabi B. EGCG targeting efficacy of NF- $\mathrm{KB}$ downstream gene products is dictated by the monocytic/macrophagic differentiation status of promyelocytic leukemia cells. Cancer Immunol Immunother. 2012;61(12):2321-31. [DOI:10.1007/s00262-012-1301-x]

35. Kretsovali A, Hadjimichael C, Charmpilas N. Histone deacetylase inhibitors in cell pluripotency, differentiation, and reprogramming. Stem Cell Int. 2012;2012. [DOI:10.1155/2012/184154] 
36. Takahashi T, Kobori M, Shinmoto H, Tsushida T. Structure-activity relationships of flavonoids and the induction of granulocytic-or monocytic-differentiation in HL60 human myeloid leukemia cells. Biosci, Biotechnol Biochem. 1998;62(11):2199-204. [DOI:10.1271/bbb.62.2199]

37. Bestwick CS, Milne L, Duthie SJ. Kaempferol induced inhibition of HL-60 cell growth results from a heterogeneous response, dominated by cell cycle alterations. Chem Biol Interact. 2007;170(2):76-85. [DOI:10.1016/j.cbi.2007.07.002]

38. Kang HJ, Youn YK, Hong MK, Kim LS. Antiproliferation and redifferentiation in thyroid cancer cell lines by polyphenol phytochemicals. J Korean Med Sci. 2011;26(7):893-9. [DOI:10.3346/ikms.2011.26.7.893]

\section{How to Cite This Article:}

Jokar M H, Sedighi S, Moradzadeh M. Differentiation-Inducing Activity of the Phyto-polyphenols Epigallocatechin-3-gallate and Kaempferol on NB4 Cells. J Adv Med Biomed Res. 2021; 29 (137): 339-345

\section{Download citation:}

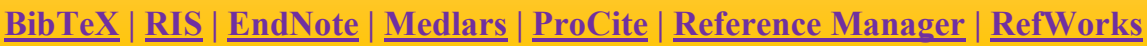

\section{Send citation to:}

Mendeley 2 Zotero : 